\title{
대순진리회의 수도 요체와 심신 수양
}

\section{양옌(楊燕)}

중국사천사범대학 · 부교수

I . 대순진리회의 수도 요체 - '성, 경, 신'과 심신수양

II. 대순진리회의 대도(大道)윤리

- '해원상생, 보은상생'과 심신수양
III. 대순진리회의 실천 수도

- '포덕교화, 근언신행(謹言慎行)' 과 심신수양

한국의 대순진리회는 증산 성사의 가르침으로부터 비롯되어 발 전한, 한국 사회에 상당한 영향력을 가지고 있는 종교단체이다. 1 969년 창설된 대순진리회는 포덕, 교화, 수도를 삼대 기본사업으 로, '음양합덕, 신인조화, 해원상생, 도통진경'을 종지로, '안심, 안 신, 경천, 수도'를 사강령으로, '성, 경, 신'을 수도의 삼요체로 삼 고 있다. 교단은 인간개조와 포덕천하, 구제창생, 보국안민을 통하 여 지상천국을 건설하는 것을 목표로 하고 있다. 대순진리회는 수 도의 사상적 측면에서 아주 다양한 내용을 포함한다. 거기에는 무 격(巫䙺), 유(儒), 석(釋), 도(道) 등이 있다. 대순진리회의 도인들 은 대순사상을 바탕으로 근엄하고 세밀한 실천수도를 수행하는데, 그 내용을 살펴보면 중국의 유, 불, 도의 양생문화와 많은 공통점 이 있는 동시에 또한 뚜렷한 한국 문화의 특색을 띠는 부분도 있 다. 이런 면들은 개인수도와 사회적 안정을 실현하는 데 큰 도움 이 된다.

* 중국 河南省 新乡 출신, 철학박사, 사천사범대학 중국철학과 문화연구소 부교수. 


\section{I . 대순진리회의 수도 요체}

\section{- '성, 경, 신’과 심신수양}

'안심, 안신, 경천, 수도'의 사강령이 대순진리회의 신도들이 지 켜야 할 가장 기본적인 행위규범이라면, '성, 경, 신'의 삼요체는 사강령을 실천하기 위한 내면적 수양으로서 모든 수도활동의 근본 이 되는 것이다. '성, 경, 신' 삼요체 중에서 '성'을 가장 근본적인 것으로 생각하는데 그 이유는 오직 '성'을 갖춘 사람만이 '경'과 '신'을 논할 수 있기 때문이다. 반대로 마음속에 망념이 있거나 경 거망동을 하는 사람들은 상제에 대한 '경'과 '신'을 잃게 된다.

『예기· 중용』에 “성실은 하늘의 이치요, 성실한 사람이 되는 것 은 인간의 이치다(誠者, 天之道也; 誠之者, 人之道也)”, “성실함은 만물의 시작으로 성실함이 없으면 만물도 없다(誠者, 物之終始不誠 無物)”라고 하였다. ‘성실(誠)'은 ‘이룸(成)'과 상통하는 면이 있는 데, 천지는 말을 하지 않으며, 누군가가 주지 않아도 스스로 얻게 되고, 끊임없이 내 주어도 마르지 않으며, 만물을 잃어버림도 없고, 버리지도 않으며, 각자는 자신이 원하는 것을 얻게 되고, 모든 것 이 자연스럽게 이루어진다. 이것이 바로 하늘의 이치이다. 여기서 가장 중요한 특징이 바로 '성(誠)'이다. 지극한 도는 지극한 성실에 서 나오며 순수하게 지극한 선(善)을 이루었을 때 만물이 '이루어 (成)'지는 것이다. 만물은 자연의 이치(道)에 의해서 생겨나고, '성 (誠)'에 의해서 형체를 이룬다. 이렇게 모든 것은 각자의 '본성(性)' 과 '성실함(誠)'을 갖추게 되는 것이다. '성'은 만물의 시작으로서 성이 없으면 만물은 생성될 수 없을뿐더러 존재할 수도 없다. 『대 학(大學)』에 “마음을 바르게 하고자 하는 자는 먼저 뜻을 성실하게 해야 한다(欲正其心者先誠其意)”고 하였다. 뜻이 성실해야 마음가 짐이 바르게 되고, 마음가짐이 바르게 되어야 몸이 안정될 수 있 
다. 곧 '성(誠)'은 '안심', '안신'의 전제 조건이다. 유가 경전의 이런 사상은 대순사상과 거의 일치한다. "대순지침』에 '성'에 대한 해석 이 나오는데 “성 자체는 하늘의 도요, 성하고자 함은 사람의 도이 니, 지극한 성으로 바르게 도 닦기에 힘써야 한다(誠者天之道, 誠之 者人之道至誠修道者也)” 1 ), “성이 아니면 만물도 존재하지 못한다 $\ldots$ 성의 소귀함을 깨달아 봉행하여야 한다 $\cdots$ 성은 거짓이 없고 꾸밈이 없이 한결같이 상제님을 받드는 일이다(若誠之無有則萬物亦 不復存在 $\cdots$ 須悟誠之所貴, 並奉行之 $\cdots$ 毫無掩飾一心一意地伺奉上 帝).”2)라 하였다. 여기서 알 수 있듯이 대순진리회에서는 지극한 정성과 올바른 마음을 가지는 것을 수행의 근본으로 하고 있다.

'성'은 어떻게 이룰 수 있는가? 대순진리회의 교리에 '무자기'라 는 가르침이 있다. 『대순지침』은 '성'에 대하여 “천도의 운행은 차 착이 없으므로 남이 모름을 괘의치 말아야 한다.(天道之運行無有 差錯，因此勿介意他人不知我之誠心)”3)고 하였다. 『대학』에도 비슷 한 내용이 있는데 “지독한 냄새를 싫어하고, 아름다운 경치를 좋 아하는 것처럼 자신을 속이지 말라(自欺也, 如惡惡臭如好好色)” 라는 문장이 있다. 그 뜻인즉 자신을 속이지 말고, 남도 속이지 말 며, 거짓이 없이 진실하게 살아야 한다는 것이다. 마치 아름다운 경치를 좋아하고 지독한 냄새를 싫어하듯이 자연스럽게 나오는 본 성에 따라 나타나는, 거짓과 위선이 없는 감정이 바로 '성'이다. 유가의 수행방법에 “군자는 혼자 있을 때 더욱 신중해야 한다(君 子慎獨)"는 말이 있는데, 즉 혼자 있을 때에도 자신의 마음가짐을 잘 가져야 한다는 것이다. 다시 말하자면 사람이 많은 장소든 혼 자 있을 때든 항상 내면에서 꿈틀거리는 생각을 경계해야 하는데, 이것은 『중용』에서 말하는 "남의 눈에 띄지 않더라도 신중해야 하 고, 남의 귀에 들리지 않더라도 두려워할 줄 알아야 한다(戒慎乎

1) 대순종교문화연구소편찬, "대순지침』, 간체본 (대순진리회출판부, 2010), p.20.

2) 같은 책, p.29.

3) 같은 책, p.28. 
其所不睹, 恐懼乎其所不聞)”는 것을 의미한다. 이런 내용들은 『대 순지침』에서 말하는 “성은 기심이 없어야 한다(誠不得有欺心)" 4 )는 사상과 일맥상통한다.

대순진리회의 '성'에 대한 해석의 많은 부분은 수도 과정에서 지 켜야 할 도덕규범이나 도덕적 자각에 대한 것이다. 수도를 하는 사람이라면 가장 먼저 경계해야 할 부분이 내면에서 꿈틀거리는 갖가지 사념(邪念)이 아니겠는가? 불교의 경전에서는 생각의 차이 가 하늘과 땅의 차이를 나타낸다고 말한다. 내면에서 꿈틀거리는 생각은 처음에는 감춰져서 잘 드러나지 않지만 언젠가는 발현하게 된다. 이런 현상에 대하여 『대순지침』에서는 "모든 일이 내심의 소정에 따라 몸으로 표현되는 법이다(所有的事情, 依內心之所定皆 顯于身)”5)라고 하였다. 또한 『대학(大學)』에서는 “성실은 마음에 있지만 표현은 밖으로 드러난다(誠于中, 形于外)”, “부유하면 집이 넉넉해 보이고, 덕이 많은 사람은 몸이 풍요로워 보이며, 마음이 넓은 사람은 몸이 편안해진다(富潤屋, 徳潤身, 心寬體胖)”라고 하 였다. 불교에서는 “형상은 마음에서 생긴다(相由心生)”라고 하였으 며, 문학가들은 “눈은 마음의 창이다(眼睛是心靈的窗戶)”라는 표현 도 자주 쓴다. 이런 것들은 비록 사용한 단어는 다르지만 그들이 말하고자 하는 의미는 같은 것이다.

중국 청나라 시대 도교 전진도(全真道) 용문파(龍門派) 11 대 종 사인 류일명(劉一明)은 『신실팔법 - 성(神室八法·誠)』에서 내단수 련의 시각에서 수도인들에게 있어 '성'이 얼마나 중요한가에 대하 여 서술하였다.

성(誠)이란 하나의 법으로서 마치 신실(神室)의 기초와 같 은 것이다. 건물의 기초를 쌓을 때 튼실하게 잘 쌓아야만 만 물을 실을 수 있는데, 신실축조의 성패도 여기에 달렸다. ......

4) 같은 책, p.30.

5) 같은 책, p.29. 
무릇 수도하는 사람은 성을 멀리해서는 안 되며 멀리하면 道 가 아니다. 멀리 해서는 안 되는 도의 중요한 부분은 성실이 며, 성실해야만 대도(大道)를 배울 수 있고, 대도를 알 수 있 으며, 대도를 이룰 수 있다. 성실하지 못하면 마음이 순수하 지 못하고, 마음이 순수하지 못하면 의혹이 생기는데, 의혹이 생기면 망념이 생기고, 망념이 생기면 행위가 확실치 못하게 된다. 그렇게 되면 점점 허위에 빠져들게 되고, 행동거지가 번뇌에 가득 차게 되어 도와 단절되게 되며, 영으로 통하는 길도 막혀 버린다. 도를 밝히기 위해서라면 어찌 먼 길을 마 다할 수 있겠는가?(誠之一法, 乃种室之基址。基址之為物, 堅 實敦厚，無物不載，神室成敗，皆在於此……蓋道也者不可須央 離也, 可離非道也。不離之道貴乎誠, 能誠則大道可學, 大道可 知，大道可成。不誠則心不純，心不純則疑惑生，疑惑生則妄念 起，妄念起則腳根不實，一行一步入于虛假，一舉一動俱是煩 惱，隔絕大道，閉塞靈窟，而欲明道，不愈遠乎？)6）

이 문장에서 볼 때 류일명은 '성'을 내단수련의 기초와 도를 성 취하는 데 필수조건으로 삼았다. 류일명은 오직 '성'한 사람만이 '도'를 논할 수 있다고 하였다. 왜냐하면 '성'은 인성의 순수함을 의 미하며, 순수한 마음이 있어야만 도에 집중하고 의심이 생기지 않 으며, 의심이 생기지 않아야 확신을 갖고 수도할 수 있기 때문이 다. “성실한 사람은 순수하고 전일(專一)하며 성실하고 거짓이 없 다. 숨김도 없고 속임도 없다. 선한 사람은 그의 성실함으로 하여 순수해지고 어리석은 잔꾀를 버리며 한번 마음을 정하면 다시 바 뀌지 않는다. (夫誠者、醇厚也、專一也、老實也、無欺也、不隱也、不 瞞也。善用其誠者返朴歸醇，黜聰毀智，主意一定，始終無二。）” 류일 명은 또한 아래와 같이 말하였다.

성실이란 무엇인가? 안위를 계산하지 않고, 일심을 갖고 앞으로 나아가며, 언사가 거짓이 없고, 행동이 괴이함이 없 다. 어디를 가도 능히 안정을 취하고, 환경이 바뀌어도 적응 을 잘 한다. 즐거운 일이 있어도 기뻐하지 않고, 역경을 마주

6）[清]刘一明：『道书十二种』，北京：书目文献出版社,1996, p.390. 
해도 걱정하지 않는다. 오직 선한 것을 고집하고, 올바른 것 을 지키며, 죽을 때까지 마음속에 도를 간직하고 영원히 변 치 않는다. 잘못을 범하면 바로 고치고, 선한 행위는 바로 행 한다 $\cdots$ 항상 진실을 추구하고 올바름을 지키며, 본분을 중 요하게 생각하고 성실함을 우선으로 삼으며 성(性)과 명(命) 외에는 아는 것이 없고, 도와 덕을 제외하고는 관심이 없다. 남이 한번에 배운 것을 백 번 반복해서라도 익히며, 남이 열 번 해서 배운 것을 천 번 행해서라도 익힌다. 이렇게 수도하 면 어리석은 자도 반드시 총명해지고, 약한 자도 반드시 강 해진다. 이것이 성실함의 법칙이니 어찌 사소하다고 무시할 수 있겠는가! (何為誠? 安危不計, 一心向前, 出言無偽詐, 行 事不怪異，隨地而安，遇境而就，到安樂處不喜，逢困難時不 憂，擇善固執，順守其正、至死抱道、永無變遷、有過即改、遇 善即行 … 處處歸真，事事守正，以本分為要，以老實為先，性 命之外別無所知, 道德之外余無所曉, 人一能之己百之, 人十能 之己千之。果能此道矣，雖愚必明，雖柔必強，誠之一法，豈小 補雲哉！)7）

이렇게 '성실함'이라는 내면적 도덕품성은 인간으로 하여금 더욱 정직하고 안정되며 오래 지속되게 한다. 뿐만 아니라 '성'은 수도자 들로 하여금 더욱 순수해 지고, 어리석음을 버리게 한다. 크나큰 도(道)를 성취하려면 먼저 이렇게 얼핏 보기에는 어리석지만 끈기 있는 마음이 필요하다. 수많은 역사적 사건들이 증명했듯이 겉으로 보기에 어리석어 보였던 사람들이 결국 큰 성취를 이루는 경우가 많다. 반대로 겉모습은 영리해 보이지만 학문에 있어서 깊이 파고 듦이 없었기에 교만하고 소홀히 하는 마음이 쉽게 생기게 되고 결 국 아무것도 성취하지 못하는 사람도 많았다. 이러한 사실은 노자 의 “큰 지혜는 어리석게 보인다(大智若愚)”는 말을 생각하게 한다.

중국의 유교경전이나 도교사상을 볼 때 모두 '성'을 잘 지키면 마음속에 헛된 잡념이 일어나지 않는다고 하였다. '성'하면 기운이 솟구쳐 내면이 더욱 안정되며 번뇌는 사라진다. 『대순지침』은 “심

7) 같은 책. 
안신태(心安身泰)란 마음이 안정되어야 몸이 태평하다는 뜻이다.” 라고 하면서, “몸의 병에는 약이 있으나 마음의 병은 고치기 어렵 다(身病可藥, 心病難醫)”는 여동빈의 말과, “모든 병이 마음에 따 라 생긴다(諸病由心起)”8)는 고인들의 격언을 인용하고 있는데, 이 것은 바로 마음이 몸을 주재하며 마음의 건강이 곧 바로 몸의 건 강에 영향을 준다는 것을 밝힌 것이다. 성심을 수련하면 마음이 안정되고, 마음이 안정되면 정신이 안정되는데, 정신이 안정되면 걱정이 사라지기에 몸이 건강해지는 것이다. 명나라의 장개빈(張 介賓)은 『유경(類經)』에서『경맥편(經脈篇)』을 인용하여 “선천의 기(氣)는 기가 정(精)으로 화(化)하고, 후천의 기는 정이 기로 화한 다. 정과 기는 더불어 살아야 하는데 정과 기가 상생하면 정신이 살아난다. 비록 신(神)은 정기에서 나오지만 정과 기를 다스리고 마음속에 있는 신과 더불어 삼자가 조화를 이룬다면 그것이 바로 도(道)이다. 요즘 사람들은 금욕으로 양생하는 법은 알지만 마음속 에 잡념이 생기면 기가 마음에 따라 흩어지는 것을 모른다. 기가 흩어져 다시 모이지 않으면 정(精)도 그에 따라 소멸된다.(故先天 之氣，氣化爲精，後天之氣，精化爲氣。精之與氣，本自互生，精氣即 是，神自生矣。雖神由精氣而生，然所以統馭精氣而虏運用之主者，則 又在吾心之神，三者合一，可言道矣。今之人，但知禁欲爲養生，殊不 知心有妄動, 氣隨心散; 氣散不聚, 精逐氣亡)”9)라고 하였다. 장개빈 은 신체적인 측면에서 성실한 사람이 장수할 수 있다는 도리를 해 석하였다. 그의 논거와 결합해 볼 때 우리는 무엇 때문에 『대순지 침』에서 '성'에 대해 그토록 강조하는지 알 수 있다.

수행의 측면에서 볼 때 대순진리회에서 '성'을 중시하는 것은 도 인들이 수도하여 성도(成道)하는 데 아주 큰 역할을 한다. 마음을 안정시키는 기능면에서 볼 때 '성'은 곧 도의 실천으로 수도인들의 신체 건강에 직접적인 영향을 준다.

8) 『대순지침』, 간체본, p.27.

9）[明]张介宾：『类经』，北京：人民卫生出版社， $1964 ，$ p.5. 
대순진리회의 삼요체 중 '경'과 '신’에는 크게 두 가지 의미가 있는데, 그 중 하나는 상제님에 대한 믿음을 끝까지 가지라는 것 이다. 이는 『대순지침』중의 “지성봉축에 변함이 없고 양면이 없어 야 경이라 하는 것이다.(至誠奉祝, 不存二心, 稱之萹敬)” 10), “믿음 은 의심 없는 굳은 신념인 것이다(信乃毫不懷疑而堅定不移的信 念)”11)라는 우당의 훈시에서 확인할 수 있다. 다른 하나는 '경’과 '신'을 인생의 기준, 수도의 기준으로 삼는 것인데 우당은 “경은 예의범절을 갖추어 처신 처세하는 것이다(敬是依禮處身處事)” 12 ), “모든 도인들은 믿음이 근본이다(信乃修道之根本)”13)라고 하였다. '경'과 '신'은 서로에게 조건이 되는데, 도인들은 존경하기 때문에 믿음이 생기고, 믿음을 갖고 존경하게 되는 것이다. 성, 경, 신의 삼요체를 모두 갖춰야만 온전하게 교리에 맞춰 처신할 수 있다. 또한 진실되고 헛됨이 없이 교리를 실천하는 것이 곧 성, 경, 신을 나타내는 것이다. "도덕경』에 "큰 덕은 도를 따르는데, 도는 황홀 하게 보인다. 황홀 속에 모습이 있고, 황홀 속에 사물이 있다. 그 토록 깊고 고요한데 그 속에 정(精)이 있다. 그 정은 지극히 진실 되며, 그 속에는 믿음(信)이 있다. (孔德之容, 唯道是從。道之炁物, 唯恍唯惚。惚兮恍兮，其中有象：恍兮惚兮，其中有物；窈兮冥兮，其 中有精。其精甚真, 其中有信)”라는 문장이 있다. 『논어·안연(論 語·顏淵)』에서 공자는 “죽지 않는 사람은 없으며, 정권은 백성들 의 신임을 잃으면 무너지게 된다(自古皆有死, 民無信不立)”고 하였 다. 여기서 알 수 있듯이 '신'은 우주의 근본인 동시에 인생의 근 본이기도 하다. 성, 경, 신을 실천한다는 것은 도인들이 천지의 도 를 따라 자아를 연마한다는 것이다.

도인들은 “예의범절을 갖추어 처신 처세한다(敬是依禮處身處 事)”, 지극한 정성을 다하여 상제님에 대한 ‘경'과 '신’을 실천하는

10) 『대순지침』, 간체본, p.29.

11) 같은 책, p.30.

12) 같은 책, p.29.

13) 같은 책, p.46. 
것은 인간의 내면에 있는 겸손함을 불러일으키기도 한다. 『역·계 사상(易・繫辭上)』에 “덕은 성대함을 말하고, 예는 공손함을 가리 킨다(德言盛, 禮言恭)”라는 말이 있는데, 공손함이란 겸손을 뜻하 는 말이다. 이에 대해『설문해자』에서는 한 걸음 더 나아가 "겸손 이란 바로 존경이다(謙, 敬也)”, “겸손하면” “존경하게 되고”, “존 경하면” “겸손하게 된다”고 해석하였다. '겸손'은 인생의 미덕이며 생존의 예술이기도 하다.

『역(易)』에 『겸(謙)』괘가 있는데 곤상간하(坤上艮下)의 형태를 취하고 있다. 곤은 땅, 간은 산을 뜻하는데, 이는 산이 땅 속에 있 는 모습이다. 산은 높이 우뚝 솟아 있지만 오히려 자신의 영광을 땅에 돌린다. 이렇게 자신의 '영광'을 내려놓을 수 있는 자만이 겸 손한 마음을 가졌다고 할 수 있으며, 산봉우리같이 높은 성취를 할 수 있는 것이다. 『겸(謙)』괘의『단(彖)』에서는 아래와 같이 말 하였다.

겸손하면 형통한다. 하늘의 도(天道)는 백성을 돌봄으로써 더욱 빛이 나고 땅의 도(地道)는 겸손함으로 하여 하늘로 올 라간다. 천도는 겸손함으로 비어있음을 채우고, 지도는 천도 를 받아 넘쳐남을 겸손으로 표현한다. 귀신은 넘쳐남을 빼앗 아 공허함을 채우고, 인간의 도는 넘쳐나는 자를 멀리하고 겸손(부족)한 자를 가까이 한다. 겸손은 존귀하고 빛나는 것 이다. 그것은 가장 낮은 자세로서 삶을 대하는 것으로 넘어 서기 힘든 도덕의 경지이다. 그러므로 군자로서의 최종 단계 는 곧 겸손이다. (謙, 亨。天道下濟而光明, 地道卑而上行。天 道雐盈而益謙，地道變盈而流謙，鬼神害盈而福謙，人道惡盈而 好謙。謙，尊而光，卑而不可逾。君子之終也）

천도(天道), 지도(地道), 인도(人道) 심지어 귀신의 도(鬼道)도 겸 손을 귀하게 여기기 때문에 올바른 기운을 모아 빛을 내는 것이 다. 군자는 덕행을 닦을 때 겸손을 중요하게 여겨야 하는데 오직 '겸손’이야말로 오래가기 때문이다. 『겸(謙)』괘의 앞은『대유(大有) 
』괘이고 다음은 『예(豫)』괘이다. 『역 · 서괘전(易·序卦傳)』에서는 “크다고 해서 넘쳐나서는 안 되기에『겸(㥆)』괘를 그 다음에 놓았 다. 클 뿐만 아니라 겸손하면 즐거워지기에 그 다음에『예(豫)』괘 를 놓았다.”『예(豫)』란 즐겁다는 말이다. ‘유(有)'하되 넘쳐서는 안 되며, 오직 '겸'을 더했을 때 즐거움이 오래간다. 다시 말해서 ‘경’이란 즐거움과 오래됨의 전제조건이 된다. 또 다른 각도에서 보면 ‘겸’은 곧 ‘경(敬)'이 된다. 동시에 ‘경' 또한 '겸’을 의미한다. 『역·계사전(易·繫辭傳)』에 “지극한 겸손이란, 자신의 자리를 잘 아는 자이다(致恭以存其位者也)”라고 하였다. 그 뜻인즉 겸손한 마 음으로 자신의 존재감을 유지하라는 것으로 이는 양생의 서(書)에 나와 있다.

흥미로운 것은 『주역』에『박(剥)』괘가 있는데, 『박(剥)』괘의 모 습은 『겸(謙)』괘와 정 반대로 하곤상간(下坤上艮)의 모습을 하고 있다. 즉, 산이 땅 위에 있는 것으로 그 의미는 '양(陽)'이 '음(院)' 에 의해 벗겨져 있는 모습니다. 해석하자면 과도하게 퍼뜨리고 다 니면 천도(天道)에 의해 억제될 수 있다는 것이다. 『박(剥)』괘의 의미 역시『겸(謙)』괘와 반대로 세상 사람들에게 과도한 교만과 자만은 필연코 해를 부를 수 있다고 경고하고 있으며 오직 조심스 럽게 처사해야만 몸을 보존할 수 있다고 하였다. 『역·계사전 (易·繫辭傳)』에서는 “겸손은 덕의 자루와 같다(謙, 德之柄也)”고 하여 겸손을 미덕의 핵심으로 보고 있다. 대순진리회 수도의 삼요 체 역시 '겸손(謙)'한 덕행을 수행하는 중요한 방법인데, 상제님에 대해 성, 경, 신을 행하는 자는 겸손한 미덕을 간직하고 있는 자로 서, 반드시 그 몸을 오래 보존할 수 있고 지위 또한 오래 유지할 수 있다고 하였다. “복록 성경신, 수명 성경신(福祿誠敬信, 壽命誠 敬信)” 14 )이라 하였으니, 인생의 복록이나 수명은 모두 성, 경, 신 의 천도(天道)의 법칙에 의해 결정되는 것이다.

14) 같은 책, 18 쪽. 


\section{II. 대순진리회의 대도(大道)윤리 \\ - '해원상생, 보은상생'과 심신수양}

'해원상생, 보은상생'은 대순사상의 가장 중요한 대도(大道)윤리 사상으로 도인들의 수도를 인도하는 기본적인 법칙이다. 이렇게 된 것은 구천상제가 증산 성사로서 강림하여 인세를 대순한 시기, 즉 조선말이라는 특수한 사회적 상황과도 관련되어 있다. 상제께 서는

지금은 해원시대니라. 양반을 찾아 반상의 구별을 가리는 것은 그 선령의 뼈를 깎는 것과 같고 망하는 기운이 따르나 니라. 그러므로 양반의 인습을 속히 버리고 천인을 우대하여 야 척이 풀려 빨리 좋은 시대가 오리라. (上帝日 : 當今乃解 冤時代。貴兩班而分別尊卑, 唒如掘租墳而毀族。故速廢兩班之 因習，善待賤人，冤方得解，迎和平盛世。)15）

라고 하셨다. 조선왕조는 아주 엄격한 계급제도를 실시했는데 위 에서부터 아래로 왕족, 사대부, 중인(中人), 평민 및 천민으로 나뉜 다. 그 중에서 왕족, 사대부가 『전경』에서 말하는 양반귀족인 것이 다. 각 계급 사이에는 넘어설 수 없는 엄격한 구분이 있었는데 '종 모법(從母法)’과 '일천즉천(一賤即賤)'이라는 제도가 있었다. 즉, 어 머니가 천민이면 그 자식도 천민이며, 부모 중 한 사람이 천민이 면 그들의 자식도 천민이 된다는 것으로, 태어날 때의 신분이 그 의 평생신분이 되는 것이다. 이러한 제도 속에서 양반귀족을 제외 한 나머지 모든 계층은 신분 때문에 인생의 목표가 거의 없었으 며, 특히 천민들은 아주 비참한 생활을 하였다. 뿐만 아니라 양반 귀족들 사이에서도 권력다툼이 아주 심했다. 이 외에도 조선왕조

15) 대순종교문화연구소편찬, 『전경』, 간체본 (대순진리회출판부, 2010), p.234. 
는 주변의 강대국에서 오는 수많은 무력위협에 시달려야 했는데, 이런 사회적 환경 속에서 수많은 백성들은 고통 속에서 허덕이게 되었고 죽는 것보다 못한 삶을 살았다. 증산 성사는 이런 사회현 실을 보고 나서 지금은 '해원시대'라고 선포하면서, 도탄에 빠진 백성들을 구원한다는 명확한 사상을 제시하였다. 『전경·공사』 제 1 장에는 증산 성사가 제자인 김형렬에게 다음과 같이 말씀하신 내 용이 있다.

선천에서는 인간 사물이 모두 상극에 지배되어 세상이 원 한이 쌓이고 맺혀 삼계를 채웠으니 천지가 상도(常道)를 잃 어 갖가지의 재화가 일어나고 세상은 참혹하게 되었도다。그 러므로 내가 천지의 도수를 정리하고 신명을 조화하여 만고 의 원한을 풀고 상생(相生)의 도로 후천의 선경을 세워서 세 계의 민생을 건지려 하노라。 무릇 크고 작은 일을 가리지 않고 신도로부터 원을 풀어야 하느니라。 먼저 도수를 굳건히 하여 조화하면 그것이 기틀이 되어 인사가 저절로 이룩될 것 이니라. 이것이 곧 삼계공사(三界公事)이니라.16)

위의 상제 말씀에 의하면 삼계가 상도를 잃었기에 상제께서 인 세에 강림하여 천지공사를 통하여 삼계의 조화를 이룸으로써 상생 의 세상을 만들어 주셨다고 한다. 삼계가 혼란에 빠진 이유는 곧 선천이 '상극'에 의해 지배되었기 때문인데, 조화로운 세상을 만들 려면 반드시 '상생’의 원리로 '상극'의 원리를 대체해야 한다. 하지 만 오랫동안 '상극'의 원리에 의해 지배되어온 삼계는 원한, 증오 로 가득 차 있었다. 그렇기 때문에 먼저 여러 가지 방법을 통하여 이런 원, 한을 풀어야만 '상생'의 원리로 '상극'의 원리를 대체할 수 있다.

‘상생’이라는 단어는 중국 고전에서도 자주 인용되는데, 대순사상 과 마찬가지로 아주 중요한 의미로 쓰인다. 노자『도덕경』에 '유무

16) 같은 책, p.94. 
상생(有無相生)’이라는 말이 있다. 음양오행의 이치를 보면 가장 중 요한 원칙이 바로 오행의 상생상극이다. 중국사상에서 '극(剋)'은 '생(生)'의 한 부분이고, 동시에 '생'은 '극'의 한 부분으로 본다. '극'은 정복하려 하고, '생'은 벗어나려 한다. '생'과 '극'은 병행하는 데 ‘극'해도 멸망하지 않고, ‘생’해도 난폭하지 않으며, ‘생’과 ‘극'이 서로 함께 있을 때 중용을 이룰 수 있다고 하였다. 다시 말해서 ‘화이부동(和而不同)' 해야만 만물이 생성하는 것이다. 그리고 만물 이 상생할 때 그것은 대생(大生)이 된다. 대순사상에서는 '상생'만 취하고 '상극'은 버리라고 하였는데, 아마도 '적대', '증오'의 개념으 로 '상극'을 사용한 것 같다. 대순사상에서 말하는 '상생'은 '조화 중용'을 이룸으로써 '생'한다는 중국문화의 '상생 상극'과 비슷하다.

세상 만물이 생성하는 것은 하늘의 조화와 질서에 의해 이루어 지는 것이다. 만약 한 곳이라도 막힌다면 만물이 생성하는데 불리 하게 된다. 그러므로 유가(儒家)에서는 '인(仁)'을 강조한다. '인'에 는 '생'이라는 의미가 있는데, 우리는 일상생활에서 씨앗을 '인'이 라 부른다. 왜냐하면 '인’에는 '생(生)과 발(發)'의 의미가 있기 때 문이다. 중의학에 '마목불인(麻木不仁)'이라는 용어가 있는데, 여기 서 말하는 '불인'이란 기혈이 통하지 않아 몸에 병이 나타나는 모 양을 말하는 것으로 생명의 기운이 존재하지 않는다는 의미이다. 『주역・계사하(周易・繋辭下)』에 “『역(易)』이 부족하면 변하고, 변 하면 통하고, 통하면 오래간다. 그리하여 '하늘의 도움이 있으면, 길하고 불리한 것은 없다(『易』窮則變, 變則通, 通則久, 是以“自天 祐之, 吉無不利)'”고 하였다. 즉, “통'하면 오래가고, 왕래가 없으면 불리하다는 것이다. 『주역·곤 · 문언(周易·坤·文言)』에 “군자는 황중(黃中)하며 리(理)에 통하니, 바른 자리에 몸을 거하며, 아름다 움이 그 가운데 있어 사지에 빛나며 사업을 발하나니, 아름다움의 지극함이라. (君子黃中通理, 正位居體, 美在其中而暢于四支, 發于事 業, 美之至也)”고 하였다. 황(黃)은 오행에서 '토(土)'에 속하며, 위 치는 중(中)이므로 ‘황중(黃中)'이라 한다. '이(理)'의 원래의 뜻은 
옥석의 무늬를 가리키는데, 중의학에서는 인체의 주름, 즉 피부, 근육, 내장의 무늬 등 신체의 표면을 가리키는 용어이다. 이 문장 의 뜻을 해석해 보면, 한 사람의 오장육부가 통해야 피부표면도 통하고, 그리하여 안팎이 통할 때 몸은 건강해지며 안색이 좋아져 얼굴에 빛이 난다는 것이다. 대순진리회에는 『오장주(五藏咒)』가 있는데 그 내용을 살펴보면 아래와 같다.

土脾中黃氣氣從額上重出化虏百節氣從千脈貫通百事如意萬事 如意天上天下地上地下人間萬事無不通知急急如律令17)

주문을 법술로 삼아 천상천하, 지상지하, 만사만물과 통하는 경 지에 이르는 것이 곧 생(生)을 구하기 위함이라 하겠다. 여기서도 알 수 있듯이 '통(通)'과 '생(生)’은 떨어질 수 없는 밀접한 관계에 있다. 그러므로 '생'을 구하기 위해서는 반드시 '통'한 상태를 유지 해야 한다. 이렇게 하려면 '원(冤), 원(怨), 한(恨)'을 해결해야 하 고 동시에 ‘은혜(恩)’를 보답해야 한다. 왜냐하면 은혜를 보답할 때 사회적인 인간관계가 ‘통'할 수 있으며, 동시에 ‘생'도 이룰 수 있 기 때문이다.

해원하려면 먼저 원을 제거해야 한다. 대순진리회의 도인들은 입도한 후 먼저 자신이 범한 과오를 참회하여 용서를 빈다. 이렇 게 하여 자신이 과거에 지었던 척을 푸는 것이다. 『전경』에는 “상 제께서 처음으로 따르는 사람에게는 반드시 자신이 그 동안 지내 오던 허물을 낱낱이 회상하여 마음속으로 사하여 주시기를 빌게 하고 미처 생각지 못한 허물을 하나하나 깨우쳐 주시고 또 반드시 그의 몸을 위하여 척신과 모든 겁액을 풀어 주셨도다" 18$)$, “허물이 있거든 다 자신의 마음속으로 풀라. 만일 다 풀지 않고 남겨 두면 몸과 운명을 그르치니라.”19)라는 증산 성사의 말씀이 있다. 중국

17) 같은 책, p.221.

18) 같은 책, p.145. 
의 경우 한나라 말기 장로(張魯)가 사천성에서 처음으로 도교를 창교할 때에 이와 비슷한 행위를 하였다. 『후한서·류언전(後漢 書·劉焉傳)』에 보면 “장로는 스스로를 가리켜 ‘사군(師君)'이라 불렀다. 구도하러 온 자들에게 초명(初名)은 '귀졸(鬼卒)', 그 다음 은 '제주(祭酒) $\cdots$ 등으로 이름을 지었다. 신도들에게 성실하고 신 용을 지키며 헛된 것을 듣지 말라고 하였으며, 병이 있으면 마음 속으로 뉘우치라고 하였다.(魯逐自號“師君”。其來學者, 初名哌“鬼 卒”，後號“祭酒”… 皆校以誠信，不聽欺妄，有病但令首過而已)”20)라 고 기록되어 있다. 장로가 제자들에게 마음속으로 참회하라고 가 르친 것은 그들의 병을 치료하기 위한 목적에 있다. 전해오는 말 에 따르면, 당시 수많은 사람들이 이런 방법으로 병을 고치게 되 었으므로 입교하였다고 한다.

세계의 다른 많은 종교들도 내면의 참회를 강조한다. 기독교, 이 슬람교, 불교, 유교 모두 마찬가지이다. 여기서 알 수 있듯이 참회 는 인생과정에서 아주 중요한 역할을 한다. 그렇다면 '참회'는 과 연 내면 수양의 작용을 하는 것일까? 지금까지의 많은 역사적 사 실에 비춰 봤을 때, 이는 맞는 말이라 할 수 있겠다. '참회’란 사 실은 자신의 과오를 뉘우치는 것을 말한다. 증자(曾子)는 “나는 하 루에 세 번 자신의 잘못을 뒤돌아본다(吾日三省乎吾身)”라고 하였 다. '참(懺)'이란 자신의 과거를 뒤돌아보고 자신의 과오를 뉘우치 는 것을 말한다. '회(悔)'란 반성에서 나오는 미안한 마음과 고치고 자 하는 마음을 말한다. 참회란 자신의 과오를 뉘우쳐 몸에 깃들 어 있는 원한을 풀어 주어 생명에 지장을 주는 요소들을 제거함으 로써 몸을 보존하는 것을 말한다. 그리고 참회자로 하여금 자신의 죄책감을 떨쳐버리게 하여 내면의 부담을 줄이고 부단한 자아 반 성을 통해 지혜를 얻게 하여 생명의 힘을 키워가게 한다. 인간은 참회를 통하여 과오를 뉘우칠 수 있으며, 해원할 수도 있고, 또한

19) 같은 책, p.250.

20）[宋]范晔撰，[唐]李贤等注, 『后汉书』，北京：中华书局 1965年版，第9册, 卷75 p.2435. 
병도 고칠 수 있다. 반대로 “자기를 반성하여 보지 않고 불만과 불평을 감정화하여 고집한다면 스스로 상극을 조장하는 것이다. (不反省自己，一味發泄不本不滿，則只能助長相克之勢)”21)라고 하였 다. 자아반성은 우리가 신중히 해야 할 문제이다.

여기서 중요한 점은 대순진리회에서 말하는 해원은 단지 개인 한 사람의 해원이 아니라 우주의 질서를 바로잡는 해원이라는 것 이다. 그렇기 때문에 대순진리회 도인들은 개개인으로 시작하여 자 신의 원한을 해결할 뿐만 아니라 땅의 원한, 천민의 원한, 여인의 원한 등 모든 원을 해결해 주고자 한다. 즉, 삼계의 모든 불평등을 해소하고 불합리한 부분을 바로잡는 것이다. 『전경』에 상제께서는 “명부의 착란에 따라 온 세상이 착란하였으니 명부 공사가 종결되 면 온 세상 일이 해결되느니라.”22), “이제는 해원시대니라. 남녀의 분별을 틔워 제각기 하고 싶은 대로 하도록 풀어 놓았다.”23), “이 제 해원시대를 당하였으니 천한 사람에게 먼저 교를 전하리라”24), "어떤 사람을 대하더라도 다 존경하라. 이후로는 적서의 명분과 반 상의 구별이 없느니라.” ${ }^{25), ~ “ ㅅ ㅓ ㄴ ㅊ ㅓ ㄴ ㅇ ㅔ ㅅ ㅓ ㄴ ㅡ ㄴ ~ ㅎ ㅏ ㄴ ㅡ ㄹ ㅁ ㅏ ㄴ ~ ㄴ ㅗ ㅍ ㅇ ㅣ ㄱ ㅗ ~ ㄸ ㅏ ㅇ ㅇ ㅡ ㄴ ~ ㄴ ㅗ ㅍ ㅇ ㅣ ~}$ 지 아니하였으되 이것은 지덕이 큰 것을 모름이라. 이 뒤로는 하늘 과 땅을 일체로 받들어야 하느니라.” 26)라고 하셨다. 이렇게 천지의 높고 낮음을 없앤 것, 계급제도의 극복 및 남존여비의 불평등을 해 소하는 것은 과거든 현재든 계급분화가 있는 한국에 있어서 모두 중요한 의미를 갖고 있다. 이런 불평등으로 하여 생기는 사회적 문 제를 해결하는 것 역시 해원의 역할이라 하겠다. 세상에 원, 한이 적을수록 '생(生)'의 기운은 점점 강해지며 이 기운에 따라 막힘이 줄어들기에 만물은 생명의 활력을 띠는 것이다.

21)『대순지침』, 간체본, p.58.

22)『전경』, 간체본, p.95.

23) 같은 책, p.105.

24) 같은 책, p.159.

25) 같은 책, p.235.

26) 같은 책, p.245. 
해원의 다른 측면은 보은이라 할 수 있다. 해원과 보은은 상보 상조의 관계에 있는데, 이는 곧 도인들이 행하는 수도의 양 날개 라 생각된다. 해원을 통하여 과거의 장애를 제거하고, 보은을 통하 여 현재의 덕을 쌓는 것이다. 『성경』에서도 “모든 일에 감사하라. 감사의 마음을 가슴속에 품는 것은 신도들의 미덕 중 하나이다.” 라고 하였다. 보은을 하려면 항상 감사의 마음을 간직해야 한다. 그 의미는 인간관계에 있어서 다른 사람이 베푼 은혜를 항상 고맙 게 생각해야 한다는 것이며, 더 나아가 천지가 우리에게 베푼 은 혜도 감사하게 생각해야 한다는 것이다.

인간은 사회적인 동물이기 때문에 다른 사람과의 관계에 있어서 즐거울 때도 있고, 불편할 때도 있다. 어떤 관계든지 막론하고 모 두 자신에게 주어진 것이라 하겠다. 순탄한 관계는 우리를 앞으로 나아가게 밀어주며, 역경은 우리로 하여금 자신을 돌이켜 보아 스 스로의 품성과 능력을 높이도록 한다. 그렇기 때문에 타인이 어떤 행동을 하든지 자신에게는 모두 은혜인 것이다. 이런 은혜는 항상 감사하게 생각해야 한다. 그들의 도움도 감사해야 하고 그들의 버 림도 감사해야 한다.

하늘이 베푼 것에 대한 감사도 마찬가지이다. 『전경』에 상제께 서는 김형렬에게 말씀하시기를 “이마두는 천상과 지하의 경계를 개방하여 제각기의 지역을 굳게 지켜 서로 넘나들지 못하던 신명 을 서로 왕래케 하고 그가 사후에 동양의 문명신을 거느리고 서양 에 가서 문운을 열었느니라. 이로부터 지하신은 천상의 모든 묘법 을 본받아 인세에 그것을 베풀었노라. 그리하여 서양의 현대문명 이 열리게 되었노라”라고 하셨다”.27) 하지만 상제께서는 또 이렇 게 말씀하셨다.

그 문명은 물질에 치우쳐서 도리어 인류의 교만을 조장하 고 마침내 천리를 흔들고 자연을 정복하려는 데서 모든 죄악

27) 같은 책, pp.147-148. 
을 끊임없이 저질러 신도의 권위를 떨어뜨렸으므로 천도와 인사의 상도가 어겨지고 삼계가 혼란하여 도의 근원이 끊어 지게 되었다. ${ }^{28)}$

아주 멋있는 말이다. 이는 오직 물질 지상주의에 있는 현대사회 의 병폐를 정곡으로 지적하였다. 오늘날 급속한 성장을 이뤄낸 나 라들은 모두 환경문제에 봉착하게 되었다. 이런 환경문제는 자연 을 훼손함과 더불어 인간 자신에게도 해를 끼치게 되었다. 문제의 원인은 인간의 과도한 자신감에서 나온다. 수많은 사람들은 인류 가 현재 취득한 성과가 자신의 노력에 의해서 이루어졌다고 생각 한다. 국가정부도 마찬가지로 표면적으로는 환경문제를 '중요시'여 기는 것 같지만 사실상 경제적 효과를 가장 먼저 생각한다. 그들 은 “인간은 자연을 이길 수 있다(人定勝天)”고 생각하는데 이런 위험하고 교만한 발상은 비록 'GDP'라는 면에서는 발전을 거둘지 모르지만 환경오염으로 인한 생태계는 심각한 파괴를 입고 만다.

이상의 내용을 종합해 볼 때, 교만하고 안하무인적인 태도나 행 동의 해로운 점은 말하지 않아도 알 수 있다. 현재 우리의 삶에서 필요한 모든 것을 보면 자연에서 얻지 않은 것이 어디 있깄는가? 몇 년 전 중국 사천성에서 일어났던 지진이 생각난다. 필자는 당시 사천성 성도에 있었는데 아주 강렬한 지진을 경험했다. 천지가 요 동쳤고, 모두들 놀라서 밖으로 뛰어나갔다. 사람들은 삼삼오오 모 여서 수다를 떨었는데 한 사람이 말하기를 원래 주말에 출근하지 않아서 편히 쉬려고 했는데 지진 때문에 며칠은 제대로 잘 수도 없을 거라고 했다. 모두 겁에 질려 있었는데, 그때 나는 마음속의 격정을 금할 수 없었다. ‘하늘의 은혜(上天的恩賜)'라는 것이 무엇 인지 새삼 느끼게 되는 순간이었다. 주말의 편안한 휴식은 아주 소 박한 일상이며 자신의 의지에 의해 결정된다고 생각했다. 하지만 지진 때문에 잠을 잘 수 없는 것, 이것은 아마도 하늘의 뜻이며,

28) 같은 책, p.148. 
우리 삶의 모든 것은 자신의 의지에 의해 결정되는 것이 아니라 하늘의 뜻에 의해 결정되는 것이라는 것을 깨달았다. 그렇기 때문 에 우리가 하루하루 편안한 삶을 살아가는 것을 하늘에 감사해야 하는 것이 아니겠는가?

'보은'도 마찬가지로 우리는 항상 겸손한 마음을 가지고 살아야 하는데, 특히 하늘에 대해 겸손한 마음을 가지고 경거망동 해서는 안 되며, 고개를 숙여 자신을 낮추고, 내면의 오만함을 버려야 한 다. 이렇게 하면 마음속의 나쁜 기운이 사라지고, 따뜻하고 유순한 마음으로 자연과 일체 생물을 대하게 된다. 이런 사람은 반드시 즐거운 사람일 것이다. 그렇기 때문에 “인자한(仁) 사람은 걱정이 없다(仁者無憂)”고 하는 것이다. “걱정이 없는(無憂)” 인자한(仁) 사람은 반드시 장수하는 사람이다. 공자도 "도로 수신(修身)하고 인(仁)으로 수도하라(修身以道, 修道以仁)”, “덕이 후하면 반드시 장수한다(大德必得其壽)”, “지혜로운 사람은 즐겁고, 인자한 사람 은 장수한다(智者樂, 仁者壽).”라고 하였는데, 모두 같은 이치를 설 명한 것이다. 하늘에 대해 존경과 감사하는 마음을 가진 사회는 또한 하늘의 보살핌을 받을 것이다.

모든 원한이 풀어지고, 모든 은혜를 다 갚았을 때 삼계가 조화 롭고 통하게 될 것이다.『예기 - 악기(禮記 - 樂記)』에 이런 시대를 묘사하여 아래와 같이 말하였다. “땅의 기운이 상승하고, 하늘의 기운이 하강하며, 음양이 서로 마찰하고, 천지가 서로 흔들리는데, 소리를 내면 마치 천둥과 같고, 진동을 하면 비바람이 일며, 움직 이면 사시(四時)가 되고, 열을 내면 일월이 된다. 그렇게 되면 만 물이 흥할 것이다. 이렇기 때문에 악(樂)을 아는 사람은 천지의 조 화를 이루는 것이다(地氣上齊, 天氣下降, 院陽相摩, 天地相蕩, 鼓之 以雷霆，奮之以風雨，動之以四時，暖之以日月，而百化興焉。如此， 則樂者天地之和也)”。여기서 ‘악(樂)’은 곧 ‘화(和)’이고, ‘화’는 곧 '악'이다. 천지인이 모두 조화를 이뤄 멋진 음악을 연주할 때 대생 (大生)의 경지에 도달할 수 있는 것이다! 


\section{III. 대순진리회의 실천 수도 \\ - '포덕교화, 근언신행(謹言慎行)'과 심신수양}

『대순지침』에 “마음으로 닦고 몸으로 행하여 심신이 일치가 되 도록 하여야 한다.(須以心修煉，身體力行，使身心達到統一)”29)는 말이 있다. 대순진리회 수도의 요체와 윤리사상이 이론적인 면에 서 수도생활의 지침이 된다면, 그 실천수도는 어떻게 도인들이 원 하는 바를 성취할 수 있는가에 대한 구체적인 행동방침을 제시한 다. 도인들이 수도의 법칙을 지키고 실천하며, 수도의 목적을 이룰 때, 즉 도인들이 수도를 통하여 안정을 찾고 건강해진다면 음양합 덕, 도통진경을 이룰 수 있는 것이다.

대순진리회에서는 도인들의 실천수도 면에서 두 가지 측면을 강 조하는데, 즉 포덕교화와 근언신행이다. 근언신행은 자아발전을 위 한 도인들의 내적 수련이며, 포덕교화는 도인들이 외부세상에 대 순사상을 알리고 가르치는 것을 말한다. 양자는 동전의 양면과 같 이 떨어질 수 없는 관계에 있다. 다른 사람을 포덕, 교화 하려면 도인들 스스로가 먼저 말과 행동에 조심해야 한다. 왜냐하면 말과 행동을 조심하는 것 자체가 곧 포덕교화에서 다른 사람의 모범이 되기 때문이다.

대순진리회의 '포덕'은 세상 사람들에게 지상선경을 만드는 길을 알려주는 것이고 '교화'는 도인들에게 교의를 가르쳐 그들의 신앙 을 확고히 하기 위한 것이다.30) '포덕'은 '교화'에 의해 발전되고, '교화'는 '포덕'에 의해 실천된다. 대순진리회에서는 도인들이 교화 할 때 반드시 진실되게 할 것과 더불어 시간과 장소에 맞춰 할 것 을 강조하는데, 그 이유는 도인들로 하여금 신앙의 목적을 잘 이

29) 『대순지침』, 간체본, p.23.

30) 같은 책, pp.22-23. 
해하여 신앙심을 깊게 하려는 데 있다. 도인들은 '포덕하는 사람' 인 동시에 '포덕되는 사람'이기도 하다. 이런 과정을 거치면서 교 리에 대해 새삼 되새기게 되는데, 도인들은 그 과정에 참여함으로 써 쓸데없는 잡념을 버리고 심신을 집중하여 수행하는 것이다. 현 대 의학이 증명하다시피 깊은 생각에 빠져있는 사람의 뇌파는 명 상하는 사람의 뇌파와 비슷하게 나타났다. 이런 뇌파는 긍정적인 에너지를 발생하는데 이 에너지는 인체의 오장육부에 균형작용을 일으켜 신체건강을 촉진시킨다. 깊은 사유를 할 때 인간의 호흡과 의식은 모두 고도의 집중상태에 있는데 이런 집중이 인체건강에 도움이 되는 것이다. 즉, '포덕'은 도인들의 종교적 신앙심을 깊게 하는데 도움이 되며, 종단을 더욱 발전시킬 수 있다. 뿐만 아니라 스스로의 건강에도 상당한 도움이 되는 것이다.

'근언신행'에 관해서 대순사상에서는 도인들에게 “항상 언행을 바르게 하여야 한다.(正其言、端其行)”고 가르치고 있다.31) 이와 더불어 대순진리회에서는 모든 조언비어를 금하고 있다. 조언비어 란 허황되고 가식된 말을 뜻한다. 『대순지침』에서는 특히 도인들 에게 조언비어를 퍼뜨려 사회적인 물의를 불러일으키는 것을 금하 고 있으며, 도인들에게 “공사를 분명히 하고, 본분을 지켜” 함부로 시국을 논하지 말며, 민심을 혼란하게 하지 말 것을 강조하고 있 다.32) 현대사회의 대부분 국가는 정치와 종교가 분리되어 있는데, 한국도 마찬가지이다. 비록 종교신앙의 자유가 있더라 하더라도 종교는 종교의 영역이 있고, 정치는 정치의 영역이 있는 것으로 서로 넘지 말아야 할 선이 있는 것이다. 만약 상대방의 영역을 침 해했을 경우 종교단체는 심각한 타격을 입게 되는데, 역사적으로 도 이런 사례가 적지 않았다. 대순진리회도 이런 역사적인 경험을 근거로 언행에 항상 조심하며, 정치와 일정한 거리를 유지할 것을 강조하는 것이다. 만약 종단이 안정적이지 못하다면 도인들이 편

31) 같은 책, p.5.

32) 같은 책, p.9. 
안하게 수도할 수 있겠는가? 대순진리회는 자아생존이라는 원칙적 인 필요에 의해서 이런 사상을 제시했으며, 이것을 실천함으로써 도인들이 편안한 수도생활을 할 수 있는 것이다.

일체 조언비어를 금한다는 사상에는 한 가지 눈 여겨 볼 점이 있는데 바로 “도에서 시한부를 운운함을 있을 수가 없다.” ${ }^{33)}$ 고 한 것이다. 도는 영원한 진리이기에 항상 평상심으로 대해야만 진정 한 '도'를 체득할 수 있다. 시한부적인 안목으로 '도'를 본다면 도 인들의 '도'에 대한 인식을 왜곡할 수 있으며 그리하여 교리에 대 한 신앙과 믿음이 흔들릴 수 있다. 그러므로 시한부적인 태도를 금하는 것은 종단의 발전과 자아보존을 위해서 꼭 필요한 생존의 요구이다.

대순진리회에서는 또 가정의 화목과 자녀의 교육문제에도 특별 한 관심을 가지고 있으며, 도인들로 하여금 주변 이웃들과 서로 도와주고 화목하게 지내며, 공중도덕과 질서를 잘 지킬 것을 강조 한다. 도인들이 입도하려면 먼저 가족의 동의를 받아야 한다. 이런 원칙들은 대순진리회가 삼계의 조화로움을 이루어내는 데 필요한 요소가 된다. 『대학』에 “수신, 제가, 평천하(修身、齊家、本天下)” 라는 말이 있다. 사소한 가정문제나 이웃간의 문제도 잘 해결하지 못한다면 어찌 아름다운 이상사회를 건설할 수 있으며 삼계의 상 생을 이루어 내겠는가?

도인들에게 자녀교육에 힘쓰라고 한 것은 창교 초기부터 도인들 의 지혜를 열어주고자 하는 데서 비롯되었다. 『전경』의 많은 부분 에서 증산 성사께서 종도들에게『대학』 등을 외우라고 하는 내용 을 찾아볼 수 있다. 이는 인생의 과정을 지혜를 깨우치는 과정이 라 해도 무방한데, 도인들의 수도는 곧 지혜를 닦는 것과 마찬가 지인 것이다. 지혜가 열려야만 인심을 통찰할 수 있고, 세상 만물 을 꿰똟어 볼 수 있으며, 대도(大道)를 깨달을 수 있는 것이다. 이

33) 같은 책, p.9. 
것이야 말로 심신수양의 최고의 경지이며, 지혜의 측면에서 봤을 때, 삶의 질을 높이는 것이라 하겠다. 도인들의 자녀교육에 대한 중시는 곧 인류의 지혜를 향상시키는 것을 중시하는 것인데, 이렇 게 하면 가정의 화목뿐 아니라 종단의 인재양성에도 도움이 된다. 이것은 대순진리회의 도인들이 수도과정에서 마음을 바르게 가지 고, 덕을 쌓으며, 재능을 키우는 지름길인 것이다. 이렇게 하여 지 극한 선(善)에 이르렀을 때 그들이 추구하고자 하는 궁극적인 목 표에 도달할 수 있다.

대순진리회의 도인들은 "명덕을 수행하고 재덕을 계발하여 지선 에 이르도록 힘써 나아가야 한다.(明明德、啟發才德、達到至善 )"34)는 것을 수행의 목표로 삼고 있다. 이 문장은 『대학』의 “대학 의 길은 명덕을 밝힘에 있고, 친민에 있으며, 지극한 선에 이르러 야 한다(大學之道、在明明德、在親民、在止于至善)”는 말을 변용 한 것인데, 이는 유가(儒家)의 도덕양생에서 일컫는 '불후(不朽)'의 세 가지 경지이다.

“명덕을 밝히라(明明德)”는 무슨 뜻인가? 먼저 ‘덕(德)'자를 보 자. 갑골문에서 '덕'은 '씨일라고 쓰이는데, 자세히 보면 네 개의 모퉁이가 있으며 이는 사거리를 뜻한다. 또한 가운데 그림은 한 쪽 눈으로 줄에 매달려 있는 공을 바라보는 모습이다. 이를 해석 해 보면 한 사람이 길 위에서 줄에 공을 매달고 길이 곧은지 아닌 지 측량하고 있는 모습이다. 즉, '덕'이란 “측량하여 길을 곧게 하 는 것” 혹은 “길이 곧은지 아닌지를 측량하는 것”이다. 이렇게 길 을 측량하는 목적은 어디에 있는가? 그 의도는 더욱 쉽고, 가깝고, 안전하게 목적지에 도달하는 길을 만드는 것이다.

금문(金文)에서는 ‘덕'을 '敦”라고 쓰고 있다. 오른쪽 아래에 '마 음(心)' 모양의 도안을 더 그려 넣었는데, 이렇게 쓰면서 의미도 더 넓어졌다. 즉, "길을 곧게 하다", “곧은 길”이라는 원래의 의미 
외에도, “마음을 바르게 하다(直心)" 혹은 “바른 마음(心直)”이라 는 의미가 추가 된 것이다. 소전문(小篆)에 이르러서는 '덕'을 “德”라고 썼다. 오른쪽 상단은 완전히 “直’자로 바뀌고, 쓰는 법도 현대의 '덕'과 거의 비슷하게 되었다.

여기서 알 수 있듯이 금문에서부터 시작하여 '덕'자는 길을 측량 한다는 의미에서 “마음을 바르게 한다(心直)”는 수양론적인 의미 로 진화하였다. 금문은 은주(殷周)시대에 청동기에 새겨진 글씨이 다. 문자의 구조로 봤을 때 적어도 은주시대로부터 '덕'자는 인간 의 수양과 연관되어 있었다. 이런 사실은 선진(先秦)시대에 나타난 문헌과 은근히 일치한다. '덕'자가 의미하는 바는 곧 인간 특유의 정신적인 추구를 나타내는 것이다.

그렇다면 '명덕(明德)'은 무엇인가? 이것은 인간이 하늘에서 부 여 받은 지극히 선한 도덕품성이라 하겠다. 하지만 인간의 품성은 출생 직후와 그 이후의 생명 과정에서 선천지기(先天之氣)의 맑고 흐림 및 후천적인 욕망 등의 원인에 의해 가려져서 어둡고 탁하게 된다. 그러나 인간은 후천적인 수행방법을 통해 마치 탁한 물에서 보석을 건져오듯 자신이 원래 가지고 있던 '명덕'을 다시 밝힐 수 있는데, 이런 과정을 '명명덕(明明德)'이라 한다. 누구든지 막론하 고 부단한 노력과 수행을 통하면 원래의 완벽한 천성을 회복할 수 있으며, 이는 “지극히 선한 경지에 도달하는 것(達于至善)”이다. 이런 사람을 '성인(聖人)'이라 부르는데, '성인’이란 죽어서도 영원 한 자(不朽)를 말한다. 이렇게 말하는 이유는 무엇일까? “이를 알 아보기 위해 '불후(不朽)'란 무엇인지를 살펴보자. '불후'라는 단어 는 『좌전·양공이십사년(左傳·襄公二十四年)』에 나온다.

첫 번째는 덕을 세우는 것이고, 그 다음은 공을 세우는 것 이며, 그 다음은 말을 세우는 것이다. 오래 되어도 사라지지 않는 것을 불후라 한다. (大上有立德, 其次有立功, 其次有立言, 雖久不廢，此之謂不朽） 
인생을 살면서 추구해야 할 가장 높은 목표는 덕(德)을 세우는 것이고, 그 다음은 공(功)을 세우는 것이며, 그 다음은 언(言)을 세 우는 것이다. 덕, 공, 언은 세월이 지나도 그 가치가 빛을 바래지 않는다. 이 세 가지 중 한 가지를 이룬 사람이면 불후하다고 할 수 있다. 성인들도 마찬가지로 그들이 성인으로 칭송 받았던 이유 는 모두 육체를 초월한 덕, 공, 언으로 세상을 풍요롭게 했기 때문 이다. 그렇기 때문에 비록 그들이 세상을 떠났다 하더라도 마치 살아있는 것처럼 영원히 추앙되며, 이것을 통하여 영생을 얻는 것 이다. '영생(永生)'만큼 높은 경지에 도달하는 '양생'이 또 어디에 있겠는가? 대순진리회 실천수도의 최고목표는 바로 인간 내면의 수양을 최고의 경지로 끌어올리는 것으로, 이는 곧 음양합덕, 도통 진경이며, 다시 말해 영원히 불후한 경지에 이르고 만세(萬歲)토록 영생하는 것이며 신(神) 그리고 성인이 되는 것이다. 



\section{大巡真理会修道要义与身心涵养}

\section{杨 燕*}

四川师范大学・副教授

\section{一、大巡真理会修道要谛 \\ - “诚、敬、信”与身心涵养 \\ 二、大巡真理会的大道伦理 \\ - “解冤相生、报恩相生”与身心涵养}

\section{三、大巡真理会修行实践 \\ - “布德教化、谨言慎行”与身心涵养}

韩国大巡真理会是由赠山的教导发展而来的一个具有相当影响力的 宗教团体。1969年創立的该教团便将布德、教化、修道定为三大基本 事业，以“阴阳合德、神人调化，解冤相生、道通真境”为宗旨，以“安 心、安身、敬天、修道”为四纲领，持守“诚、敬、信”三要谛，旨在通 过人间改造，布德天下，广济苍生，辅国安民而建设地上天国。该教 团的修道思想内容丰富, 与巫欧、儒、释、道等均有渊源爸系。在其 思想宗旨指导下, 该教团道人的修道实践细致、严谨, 其中许多内容 既与中国儒、释、道养生文化有相通之处, 又具有鲜明的韩国文化特 色，对个人身心涵养与社会安宁均有相当助力。

\section{一、大巡真理会修道要谛 - “诚、敬、信”与身心涵养}

* 河南新乡人, 哲学博士, 四川师范大学中国哲学与文化研究所副教授。 
大巡真理会 “安心、安身、敬天、修道” 四纲领可谓该教团信众最基 本的修道准则及行为规范，而 “诚、敬、信”三要谛则为信众遵从四纲 领所必须的心性修养方面的要求，也是信众从事一切修道活动的入门 法要。在“诚、敬、信”三者中，又以“诚”为最根本所在，唯“诚”者才 能谈得上“敬”和“信”，任何虚妄的念头和举动，都将破毁信众对上帝 的“敬信”。

『礼记 - 中庸』说：“诚者，天之道也；诚之者，人之道也。”又说： “诚者, 物之终始, 不诚无物。”“诚”与“成”通, 天地无言, 不待安排 而自得，周流不虚，万物无所遗，无所弃，各得其所，自然而成，这 就是天道, 它最典型的特征就是“诚”。大道至诚无妄, 纯粹至善, 所 以能 “成”万物; 万物顺道而生，因诚而形，因此，各得其性，各得其 诚。“诚”是万物资始的所在，若无诚则天地万物不能产生，也不能存 在。『大学』说：“欲正其心者，先诚其意。”意诚才能心正，心正才能 身安, “诚”是人安心、安身的首要前提。儒家经典的这些说法与大巡 真理会的思想完全一致。『大巡指针』在解释“诚”的时候就说：“诚者天 之道，诚之者人之道，至诚修道者也。”1)又说：“若诚之无有则万物亦 不复存在 $\cdots$ 须悟诚之所贵，并奉行之 $\cdots$ 毫无掩饰，一心一意地伺奉上 帝，即为诚。”2) 由此可见，大巡真理会信众修行以至诚正心为大要。

那么，怎么样才能做到 “诚”呢? 在大巡真理会的教义中，有“无自 欺”的教导。在谈到“诚”的时候，『大巡指针』说：“天道之运行无有差 错，因此，勿介意他人不知我之诚心。”3)在『大学』中也有类似的说 法：“四自欺也，如恶恶臭，如好好色。”意思就是不要自欺，也不要 欺人，做人要真实无妄，就好像喜欢美色，讨厌恶臭一样，这种喜欢 和讨厌，发自天然，出自本性，是实实在在没有一毫伪装的情感，这 就是“诚”。因此，儒家的修养方法中有“君子慎独”一语，它既指在私 密的场合, 要注意自我检点; 更有无论是大庭广众, 还是独自一人,

1）大巡宗教文化研究所编纂，『大巡指针』，韩国：大巡真理会出版部，2010，第20页。

2）同上，第29页。

3）同上，第28页。 
都要警戒自我内心意念萌动的意思，此合于『中庸』云“戒慎乎其所不 睹，恐惧乎其所不闻”，也与『大巡指针』所云 “诚不得有欺心”4)的思想 相一致。

可见，大巡真理会爸于 “诚”的论述有不少内容都旨在阐明修行中的 道德自律和道德自觉。试想一想, 还有什么比恶念萌动更让一个修行 者触目惊心呢？所以，佛教经典也常说：一念之间，凡圣天渊。而内 心的意念萌动，起初看起来似乎是隐微不显，但终究会表现出来。故 而，『大巡指针』指出：“所有的事情，依内心之所定皆显于身。”5)『大 学』中也说“诚于中，形于外”，又说“富润屋，徳润身，心宽体胖”，佛 教说“相由心生”，文学家则讲“眼睛是心灵的窗户”，这些言辞虽然不 同，但陈述的道理却相通。

中国清代全真道龙门派第十一代宗师、高道刘一明在『神室八法 ·诚』中 也从丹道修炼的角度，对“诚”在道人修行中的重要性做了解读，他说：

诚之一法，乃神室之基址。基址之为物，坚实敦厚，无物不 载，神室成败，皆在于此……盖道也者不可须央离也，可离非道 也。不离之道贵乎诚, 能诚则大道可学, 大道可知, 大道可成。 不诚则心不纯，心不纯则疑惑生，疑惑生则妄念起，妄念起则脚 根不实，一行一步入于虚假，一举一动俱是烦恼，隔绝大道，闭 塞灵窟，而欲明道，不愈远乎? 6)

在这段话中，刘一明将“诚”定位为内丹修炼的基石和修习大道必备 的品性。在他看来，唯有“诚”之人才能论“明道”之事。因为“诚”意味 着人心纯，心纯则专一于道而不疑，不疑才能踏实修习。“夫诚者，醇 厚也，专一也，老实也，无欺也，不隐也，不瞒也。善用其诚者返朴 归醇，黜聪毁智，主意一定，始终无二”，接下来，刘一明进一步指 出:
4）同上，第30页。
5）同上，第29页。
6）[清]刘一明：『道书十二种』，北京：书目文献出版社1996年版，第390页。 
何为诚？安危不计，一心向前，出言无伪诈，行事不怪异，随 地而安，遇境而就，到安乐处不喜，逢困难时不忧，择善固执， 顺守其正，至死抱道，永无变迁，有过即改，遇善即行……处处 归真，事事守正，以本分为要，以老实为先，性命之外别无所 知, 道德之外余无所晓, 人一能之己百之, 人十能之己千之。果 能此道矣，虽愚必明，虽柔必强，诚之一法，岂小补云哉！7）

可见，“诚”这一心理素养和品德特质还能使人做事本实、坚定、持 久; 同时, “诚”又能助修道者反朴归醇、黜聪去伪。修成大道所需要 的正是这种看起来有些蚌钝的坚持功夫。历史的经验以及生活事实也 证明，往往是那些看起来比较笨拙的人，反而在最后获得了更大的成 就; 而那些看起来很聪明的人, 却因为很快就对所学的东西一知牛 解，反而容易产生骄傲轻忽的情绪，最后一事无成。这不由又让人想 起老子的那句话“大智若愚”。

从中国儒家以及道教的典籍都可以看出，对“诚”的信守，能使人心 安而妄念不起; “诚”则气足，使人内心坚定而远离烦恼。大巡真理会『 大巡指针』中说：“心安身泰，是指唯心安，身得太本。”又引吕洞宾的 话：“身病可药，心病难医。”又引其他古人的话：“诸病由心起。” 8) 这些言辞都表明：心主宰身体，心灵康健影响身体康健。因为修诚则 心安，心安则神定，神定心安无烦扰则身泰。明代张介宾在『类经』一 书中引『经脉篇』说：“故先天之气，气化为精，后天之气，精化为气。 精之与气，本自互生，精气即是，神自生矣。虽神由精气而生，然所 以统驭精气而为运用之主者, 则又在吾心之神, 三者合一, 可言道 矣。今之人, 但知禁欲为养生, 殊不知心有妄动, 气随心散; 气散不 聚, 精逐气亡。”9)张氏从生理科学角度解读了为什么诚者长寿的道 理, 追溯一下张介宾的论述, 我们可以更好地体悟『大巡指针』为什么 如此强调“诚”的良苦用心。

7）[清]刘一明：『道书十二种』，北京：书目文献出版社1996年版，第390页。

8)『大巡指针』，第27页。

9）[明]张介宾：『类经』，北京：人民卫生出版社，1964年版，卷1第5页。 
从修习角度讲，大巡真理会对“诚”的奉行，必定有助于道人自身修 道的成功。从其自身所具有的心理安定功能来说, “诚”本身就是一种 道行践履，直接助力于修习者的身体康乐。

大巡真理会三要谛中的“敬”和“信”主要有两方面的意思，一是坚定 自己对上帝的信仰，“至诚奉稆，不存二心，称之为敬”10)，“信乃毫 不怀疑而坚定不移的信念”11）；二是以“敬” “信”为人生基准，为修道 基准，“敬是依礼处身处事” 12)“信乃修道之根本”13)。“敬”和“信”二者 互为条件，道人因敬而信，持信而敬。诚、敬、信三者具备，才能彻 底地依教义处身处事; 而真实无妄地实践教义, 又恰是诚、敬、信的 表现。『道德经』说：“孔德之容, 唯道是从。道之为物, 唯恍唯惚。惚 兮恍兮，其中有象；恍兮惚兮，其中有物；窈兮冥兮，其中有精。其 精甚真，其中有信。”『论语 - 颜渊』中孔子说：“自古皆有死，民无信 不立。”可见，“信”乃宇宙之根本，人生之根本。奉行诚、敬、信，这 是道人模仿天地，自我砥砺的一种火候工夫。

同时，信众“依礼处事处身”，至诚地履行对上帝的“敬”“信”，客观上可 以培植人发自内心的谦卑感。『易・系辞上』日：“德言盛，礼言恭。”所谓 “恭”含有谦逊的意思。对此，『说文解字』进一步解释说：“谦，敬也。” “谦”则“敬”，“敬”乃“谦”。“谦卑”是一种美德，更是一种生存艺术。

『易』有『谦』卦，该卦坤上艮下，坤为地，艮为山，为山在地中之象。 山峰魏峨高年, 却把自己的荣耀隐没于大地之中 ; 然而, 恰恰是这种放 下“荣耀”的谦卑情怀，才成就了山峰的崇高和伟大。『谦』卦『彖』日：

谦，亨。天道下济而光明，地道卑而上行。天道亏盈而益谦， 地道变盈而流谦，鬼神害盈而福谦，人道恶盈而好谦。谦，尊而 光，卑而不可逾。君子之终也。

10）『大巡指针』，第29页。

11）同上，第30页。

12）同上，第29页。

13）同上，第46页。 
天道、地道、人道, 甚至鬼道都以谦卑为尊, 所以能够凝聚正气而 发出光芒。君子修德, 以谦为要, 只有 “谦”能够长久。『谦』卦之前为『 大有』卦，后为『豫』卦，『易・序卦传』曰：“有大者不可以盈，故受之 以『谦』。有大而能谦必豫, 故受之以『豫』。”豫者, 乐也。“有”不可以 盈满, 惟有 “谦”方能乐、能久。换一句话来说, “敬” 是乐、久的前 提，因为从某种意义上讲，“谦”就是“敬”，而“敬”也意味着“谦”。『 易・系辞传』所谓“致恭以存其位者也”, 这表示的正是以谦恭情怀来续 存自我的存在，其养生保身的寓意跃然纸上。

非常有意思的是，『周易』中另有一卦为『剥』，其卦象与『谦』卦正好 相反，为下坤上艮，乃山在地上之形，描述的是“阳”被“阴”剥落的情 境，暗示事物过于张扬则终要被天道抑制。其意与『谦』卦相反而相 成，警戒世人若过于狂妄必被剥而有祸殊，唯谨慎处事方能保身。所 以, 『易・系辞传』日：“谦，德之柄也。”将谦卑看作美德中的枢要，

而大巡真理会修道思想中的三要谛恰是培养 “谦”德的重要路径, 对上 帝诚、敬、信者，必是有谦卑之美德者，亦必是能长存其身，常保其 位者。所谓“福禄诚敬信，寿命诚敬信” ${ }^{14)}$ ，表达了人生的福禄、寿命 都取决诚、敬、信的天道法则。

\section{二、大巡真理会的大道伦理 \\ - “解冤相生、报恩相生”与身心涵养}

“解冤相生、报恩相生” 是大巡真理会最重要的大道伦理, 也是指导 道人修行的基本法理。

大巡真理会道主确立宗统并提出 “解冤相生, 报恩相生”这一大道伦 理, 实在有当时朝鲜特殊的社会生态原因。『典经』中说：

14）同上，第18页。 
上帝曰：当今乃解冤时代。贵两班而分别尊卑，犹如掘祖坟而 毁族。故速废两班之因习, 善待贱人, 冤方得解, 迎和本盛 世。15)

朝鲜李氏王朝时期实行非常严格的阶级制度，从上到下，依次为王 族和土大夫、中人、本民和贱民，其中王族和士大夫就是『典经』中说 的两班贵族。各等级之间严禁逾越，而且采取“从母法”和“一贱即贱” 制度，只要母亲是贱民，小孩就是贱民。父母中一方是贱民，则所生 子女就是贱民。一个人出生时的身份往往就是他一生的身份。在这种 制度中生存，除了两班贵族外，其他的所有人几乎都将因为自己的出 身而无法有所追求, 特别是贱民, 生活尤为悲惨。而两班贵族内部也 长期充不着你死我活的权利斗争。同时, 朝鲜的历史, 又无时不件随 着来自左邻右舍强国的武力进攻和政治胁迫, 这种社会状况, 使大量 的人民内心累积无法告解的怨恨，生不如死。潧山圣师目睹这些社会 惨状，提出这一时代为 “解冤”时代，其扶危救命的思想非常明确。

『典经・公事』第一章中赠山对金亭烈说：

在先天，人与世间万物皆为相克之理所支配，世间怨恨日积月 累, 错综复杂地充斥于三界之中。天地失其常道, 各种灾祸丛 生，世间暗无天日。因此，吾欲整理天地度数，调化神明，以解 万古怨恨, 以相生之道建后天仙境, 济度世间苍生。不论大小事 应由神道解冤, 若能事先稳固度数并加以调化, 人事便以神道为 范实现自我达成，这便是三界公事也。16)

按大巡真理会教义，因为三界失调，所以上帝才降临人间，以通过 种种作为谐和三界, 使三界成为相生世界。而三界之所以混乱失调, 就是因为支配三界的先天之理是“相克”, 那么, 要建立和谐的世界, 则必须以“相生”之理取代“相克”之理。但是，因为长期“相克”之理的 支配，三界间充满了冤屈、仇恨，所以，必须通过种种修为先和解这

15）大巡宗教文化研究所编纂，『典经』，韩国：大巡真理会出版部，2010，第234页。 16）同上，第94页。 
些冤、怨、恨，“相生”之理才能取代“相克”之理。

“相生”一词在中国古代典籍中多有出现，同样也是一个非常重要的 概念。老子『道德经』中说 “有无相生” ; 阴阳五行理念最重要的一个原 则就是五行相生相克。在中国文化中 “克”是“生”的一部分，“生”亦是 “克”的一部分。“克”为制服，“生”为挣出。“生” “克”并行，“克”不至 于绝灭，“生”不至于猖狂，“生” “克”相随，而成中庸。也就是“和而不 同”，方成万物。而万物并生，才是大生！大巡真理会教义取“相生”而 去“相克”，是从“敌对”、“仇恨”之意理解“相克”，所以弃之。而其“相 生”之意与中国文化所论“相克相生”类似，即“谐和中庸”以成“生”。

盖世间万物之生，全赖上天所创造之谐和秩序。任何一处阻碍不 通，都将不利于天地万物之生。所以，儒家就讲“仁”，因为“仁”有 “生”的意思，我们在日常生活中把种子称为“仁”，也是从“生发”的意 思理解 “仁”。在中医中有“麻木不仁”之说，“不仁”即血脉不通，肌体 就会表现为疾病状态，则生机不存。『周易・系辞下』日：“『易』穷则 变, 变则通, 通则久, 是以“自天祐之, 吉无不利。”讲 “通”才能长 久，无往而不利；『周易・坤・文言』云：“君子黄中通理，正位居体， 美在其中而畅于四支，发于事业，美之至也。”黄为五行“土”的颜色， 其位居中，是为“黄中”; “理”的本意是玉石的纹理，在中医理论中, 指肌体的㬺理，也就是皮肤、肌肉、脏腑的纹理，泛指身体的表面。 这句话讲人的身体只有内部五脏六腑通了，外部皮肤表层才能通，内 外皆通，身体就很健康，人的脸色就会看起来光彩照人。在大巡真理 会教理中，有『五脏咒』，文日：

土 脾中黄气 气从额上重出 化为百节 气从千脉贯通 百事如意 万事如意 天上天下 地上地下 人间万事 无不通知 急急如律令17)

以咒语为法术，以期获得天上天下、地上地下、万事万物无不通的 境界，其目的正是为了求生，可见“通”与 “生”之枀系何等紧密！所

17）同上，第221页。 
以，要“生”则必须达到并保持“通”的状态。因此“冤、怨、恨”必要 解，“恩”必要报，因为这是社会人生“通”的爸键，亦为“生”之爸键。

要解冤就要去冤、去怨。大巡信徒初入教会, 首先忓悔自己过往的 罪, 以求饶恕，解除自己以往因无知而结下的冤、怨之缘。『典经』中 说：“上帝对初遇而追随自己的人，通常令其一一回忆过去存在的缺 失，心中忓悔，以求饶恕。上帝对于尚未意识到的错误也一一指出， 并为其消除身上的冤神和劫厄。”18) 同时指出：“若有过失，皆化解 于心。若化解不尽将危及身体和命运。”19）在中国，汉末张鲁在四川 初创道教也有与之极类似的活动。『后汉书 - 刘焉传』说：“鲁遂自号 “师君”。其来学者, 初名为“鬼卒”, 后号“祭酒”……皆校以诚信, 不听 欺妄, 有病但令首过而已。”20）张鲁道教令信徒真诚忏悔的目的主要 是治病, 而且, 据说当时有许多人确实通过这种方式医好了自己的病 痛，并因此而信奉了道教。

有意思的是，世界上几乎所有的宗教都强调信徒要能忓悔过错，无 论是基督教、伊斯兰教还是佛教、儒教，都是如此，可见忓悔在人生 命中的重要性。那么, “忓悔” 是不是真的可以达到涵养身心的作用 呢? 从大量的事实来看，应该是如此。“忓悔”其实就是反思改过，曾 子曰：“吾日三省乎吾身。”“忓”为反思自己的行为，认识自己的过 错, “悔”为由此生出惭愧心及改过心。忏悔除了可以消除由于自身过 错而给自己的生命带来的怨冤之气，从而减少生命存在中意外伤亡的 可能性，得以保全自身这一作用外，还可以帮助忓悔者彻底放下内心 沉重的罪恶感，卸除心理的包䘤，并通过不断对自我行为的反思，获 得智慧，从而提升自我生命的力量。所以，忏悔思过，可以解冤，也 可以治病。而“不反省自己，一味发泄不平不满，则只能助长相克之 势”21)，这是多么值得注意的事情！

18）同上，第145页。

19）同上，第250页。

20）[宋]范晔撰，[唐]李贤等注：『后汉书』，北京：中华书局1965年版，第9册卷75，第2435页。

21）『大巡指针, 第58页。 
不过，大巡真理会所解之冤，并不仅仅为个人一己之冤，其目的实为 重构一新和谐宇宙秩序，所以，除了信徒从个人做起，消解自身之冤 外, 她还要解地之冤, 解贱民之冤, 解女人之冤, 解所有人之冤。总 之, 三界一切不平都要铲除去, 一切不合意都要重新洗刷。『典经』载上 帝道: “因冥府发生错乱，世间随之混乱不堪。故冥府公事完成，则世 间万事皆可得解。”22) 又说：“当今为解冤时代，解除了男女之别，令 其各得所愿。”23) 又说：“如今是解冤时代，宜先传教于贫贱之民。”24) 又说：“无论所见何人，应尊称相待。今后当无嫡庶班常之分矣。”25) 又 说: “在先天惟天为上, 而不以地为上则是不知地德之深厚故矣。从今 往后天地作为一体尊待也。”26)这些取消天高地低、严格等级界限以及 男尊女卑的倡议, 无论是在过去还是现在, 对于韩国这样一个有着极深 等级观念的国家来说，都具有重要意义。对于解除因此而造成的社会问 题，同样具有化解的作用。世间怨、冤、恨越少，“生”意就会越多，顺 境増而滞障少, 万物始能生机勃然。

解冤的另一面是报恩, 二者并行相助, 为道人修行之两翼。解冤为 消往日之障, 报恩为积今日之善。『圣经』中也说：凡事谢恩。将常怀 感恩之心，作为信众的美德之一。报恩就须常怀感恩之心，其意既指 在与他人交往中, 常念他人赐予之恩; 更指人生在世要常常感念天地 赐予之恩。

人是群体动物, 在生活中必得面对他人种种作为, 有让我们愉悦 的, 也有让我们烦扰的。无论哪种, 对自我来讲, 都是一种赐予。顺 境可正面激励推动我们，逆境更可使我们警醒反思，并提升自我的品 性和能力。所以, 无论他人作何举动, 与我而言, 都是一种恩赐, 要 常怀感念之心。感谢他们的帮助，也感谢他们的舍弃。

而对上天的感赐更是如此。『典经』中记载上帝对金亨烈说法，讲到

22)『典经』，第95页。

23）同上，第105页。

24）同上，第159页。

25）同上，第235页。

26）同上，第245页。 
西洋人利玛窦打通了天地界别, 使从前互不越界的东西方神明开始往 来，利玛实死后，率东方神明前往西方开启文运，模仿天上妙法施展 于人间，此为西洋现代文明之起，但是，上帝转而说道：

然其文明者，倚重于物质，助长了人类之骄慢，以致动摇了对 天理之信心、为征服自然犯下了种种罪恶，荡涤神道权威，致天 道与人事常道皆有忤违，三界混乱，道基断绝 …227)

这段话说得极好，可以说是直指现代文明唯物质主义的最大睯端。 在今天，世界上几乎所有急速奔跑中的国家都面临着巨大的环境问 题, 在戕害自然的同时, 战害着人类自身。其根源都在于人类过度自 信。现代相当数量的人以为人类今天的所得皆由于人类自我的努力; 而令人不可思议的是，一些政府机构表面看起来似乎“重视”自然环境 问题，但落实到具体措施上却又以获取经济效益为最大追求，表现出 “人定胜天”的自傲乃至非常狂妄的心态，其结果是“GDP”提升了，而 环境污染、自然生态却遭受严重破坏!

审视上述情况，不能不感到自傲、狂妄态度与行为的极大危害。试 想我们今天活着所必须的一切, 哪一样不是来自于上天的恩赐? 说到 这里，笔者不禁想起今年四川芦山地震时的一件事。当时笔者在成 都，震感非常强烈，一阵地动山摇之后，大家都跑到了户外，在一片 露天的地方谈话。有一个邻居就说 : 本来周六不上班, 想好好睡个懒 觉, 结果也睡不成了, 恐怕这几天都睡不好了。当时也许是被惊吓得 太方害了, 我听了邻居的话, 内心感到非常激动, 忽然非常深刻地体 验到了 “上天的恩赐” 是怎么回事。周六的早晨睡个懒觉，看起来是个 很自我的小事，完全可以在自己掌控之中，可实际上能不能睡得成， 还是要看上天的意思，一切都无一遗漏地、真真切切地掌握在上天的 手里。所以, 我们今天都好好地坐在这里, 这难道不要感恩上天的赐 予吗?

27）同上，第148页。 
所以，“报恩”同样也是让我们时时心怀谦卑，尤其是在上天面前要心 怀谦卑, 减少妄念、妄作, 低下我们的头、收拢骄横的心。能够如此, 则内心的戻气自然消解，而终以温和柔顺的态度面对上苍及周围一切生 灵。这样的一个人，内心一定是愉悦淡定的，所谓“仁者无忧”。而“无 忧”之仁人，亦必是长寿之人，孔子说：“修身以道，修道以仁。” “大德 必得其寿。”又说：“智者乐，仁者寿。”讲的都是这个道理。而一个保守 对上天敬畏和感恩之心的社会，也必得上天的春顾。

当一切冤皆解，一切恩都知报之时，亦为三界致达一切和顺通达之 时，此时如『礼记・乐记』所云：“地气上齐，天气下降，阴阳相摩，天 地相荡, 鼓之以雷霆, 奋之以风雨, 动之以四时, 暖之以日月, 而百 化兴焉。如此, 则乐者天地之和也。” “乐”即是“和”, 而“和”亦是“ 乐”，天地人和美，齐鸣为大乐，大生境界成矣！

\section{三、大巡真理会修行实践 \\ - “布德教化、谨言慎行”与身心涵养}

『大巡指针』说：“须以心修炼，身体力行，使身心达到统一。”28)如 果说大巡真理会的修道要谛和大道伦理是从理论高度告诉信众修行的 法则和目标是什么的话，那么大巡真理会的修道实践就是从具体的方 法上告诉信众如何遵从和达成这些法则和目标，信众对修道法则的切 实遵行及修道目标的最终达成，也即信众身心对修道安康尚境——阴 阳合德，道通真境的最终达成。

大巡真理会信众修道实践有两个方面尤其值得爸注，这就是：布德 教化与谨言慎行。谨言慎行是信众向内的自我行事要求 ; 布德教化是 信众向外宣化大巡真理会的教义、教导。二者同样是一体两面，不能

28）『大巡指针』，第23页。 
截然分开。因为要成功进行布德教化, 信众必须谨言慎行, 而谨言慎 行本身即为布德教化的一种垂范。

大巡真理会的 “布德”，给世人指明共同建设未来仙境的途径，而 “教 化”则是对道人进行教义讲解并坚定道人的信仰真心。“布德”依“教化” 而行, “教化”为 “布德”而施。大巡真理会要求对所属道人的教化必须 热情真挚，时间、场所合宜，以使道人明了信仰、坚定信仰。从某种 层面看，道人是“布德” 者，亦是被“布德” 者。在这一过程中，教理教 义将被讨论反思，道人参与其中，身心将专注于精神运动而无暇世间 琐事。现代生理科学研究证明，沉思者的脑电波类似冥想者的脑电 波, 而这种脑电波可以产生正能量，能够对人体五脏六腑的和谐平衡 产生很大的促进作用。思考时，人的呼吸和意识都将处于高度集中状 态，而这种集中也都有利于身心健康。因此，“布德”可以帮助道人提 升自我宗教信念，可以发扬光大教会，同时，更能切实有利于道人自 我身心健康。

䏌于 “谨言慎行”, 大巡真理会要求信众 “正其言、端其行”。比如大 巡真理会严禁一切造言蜚语。造言蜚语指虚妄之语、矫饰之语。『大巡 指针』特别提到，信众不得编造谎言招致社会非议，以避受邪教指责， 并要求信众 “明公私，守本分”，不得妄论时局，扰乱民心。因为现代 社会大部分国家政教分离，韩国亦是如此。宗教信仰虽然非常自由， 但教有教域，政有政界，贸然越轨，定不利于自身生存，甚而可能会 遭受打击以致教体灭失，历史上此类事件不少，且大巡真理会自身就 有过这样的前车之鉴，虽不一定是教徒信众造言蜚语所致，但谨言慎 行，与政治保持适当距离总是比较安全。试想，教如不安，则信众之 平安喜乐何来? 所以, 这实际上是大巡真理会自身生存之必须，也是 信众保持自身康乐之必须。

禁一切造言蜚语中还有一点值得注意，即大巡真理会要求信众“勿以 时限论道” 29)，因为道乃永恒之真理，须以恒常之心看待，才能感悟

29）同上，第9页。 
“道”的真与正。随意以一时之见论“道”，极易误导信众对“道”的认识 并由此动摇对教义的信奉和遵从。所以，勿以时限论道之要求，同样 也是教会保存自身尊严和权威的生存需要。

另外, 大巡真理会特别注意道人家庭和睦和子女教育问题, 要求道 人与邻里相处要能互帮互助, 并遵守公共秩序。道人加入教团, 也必 须得到家人的同意。这些要求是大巡真理会创建和谐三界的必须。『大 学』云：修身、齐家、平天下。如果小小的家庭问题、邻里问题都不能 解决顺当和保持和美的话，又何来什么三界相生呢?

要求道人重视对子女的教育, 这与大巡真理会上帝创教之初便极其 重视对教徒智慧的开启是一致的。在『典经』中多处记载上帝要求教徒 背诵经典，如『大学』、『通鉴』等。人生的过程实为一智慧开启的过 程，修道与修智是完全一致的。只有开启智慧，通达人心，洞明万 事，才能洞明大道，此实为身心涵养的最高境界，即在智慧的层面提 升生命的品质。对道人子女教育的重视，就是对人类未来智慧提升的 重视, 在和谐家庭之外, 亦为教会准备了智力的后备。这也是大巡道 人修道过程，以正心立义，明明德，启发才德为路径，以达于至善为 终极追求的具体体现。

大巡真理会道人 “明明德、启发才德、达到至善” 30)的修行追求，其 言化用了『大学』：大学之道，在明明德，在亲民，在止于至善。其意 实为儒家道德养生之三“不朽”境界。

什么是“明明德” 呢? 首先, 我们看“徳”字。“徳” 在甲骨文中写作 㸚, 四边的符号画的是一个十字路口, 中间画的是一只眼睛在看一个 线吊着的圆球。意思是一个人在路上用线吊着一个球测量路直不直, 所以，“徳”这个字的本意是指“勘测以使路直”或“勘测路直不直”，那 么, 勘测道路的目的是什么呢? 显然是为了找到容易行进的、距离目 的地最近、最安全的路。

到了金文中，“徳”写作德，右下方加上了一个“心”的图形，意思就

30）同上，第23页。 
被引申了，除了表示“直路”或“路直”外，还表示“直心”或“心直”。到 小管中, “徳”字写作德，右上方所画的图形已经完全演变为“直”字， 写法与现代的“徳”字基本相同。

可见，从金文开始，“徳”字就从测定道路的本意中引申出了矢于“心 直”的修养意义。金文是殷周刻于青铜器上的铭文, 可见从文字构造来 看, 最晚从殷周开始, “徳” 就与人的修养联系在了一起。这一点与先 秦文献的使用情况完全一致。“徳”字所指的是人所独有的一种精神追 求。

什么是“明德” 呢? 这是一种人得之于天的至善品性。但是，在人出 生之初和以后的生命历程中, 这种品性会因为所禀承的先天之气清浊 不一, 以及后天物欲引诱等种种原因而被遮掩昏蔽, 使人的德性昏昧 不明。但是，人在后天通过一定的修习方法，就好像从混浊的水中捞 取宝珠一般，可以逐渐恢复自己本有的“明德”，这个过程也就是“明明 德” 的过程。无论什么样的人，都可以通过刻苦修炼而恢复自身本来完 美的天性，也就是“达于至善”，而这样的人就是“圣人”, “圣人”即为 死而不朽者，为什么这样说呢? 我们来看“不朽”一词。

大上有立德，其次有立功，其次有立言，虽久不废，此之谓不朽。

人生于世, 最高的追求为立德, 其次为立功, 再次为立言。德、 功、言可以历久弥新，一个人能做到三者之一，才能说是死而不朽。 这世上的圣人，其所以为圣，无一例外，都因有超越肉体之外的功、 德、言，恩泽惠及万世，因此虽死犹生，永垂不朽，得以实现生命之 最长久的存在。有什么“养生”能超越这一“永生”的境界呢！因此，大 巡真理会这一修道实践的终极追求实际上也是人类身心涵养追求的终 极境界，即阴阳合德，道通真境！即永垂不朽！万世永生！即神！即 圣者也! 


\section{【参考文献】}

大巡宗教文化研究所编纂, 『大巡指针』, 韩国: 大巡真理会出版部, 2010年版。 大巡宗教文化研究所编纂, 『典经』, 韩国: 大巡真理会出版部, 2010年版。 [清]刘一明，『道书十二种』，北京：书目文献出版社，1996年版。 [宋]范晔撰，[唐]李贤等注，『后汉书』，北京：中华书局，1965年版。 杨天宇撰，『礼记译注』，上海：上海古籍出版社，2004年版。 [魏]王嘲注, 楼宇烈校释, 『老子道德经注校释』, 北京: 中华书局, 2008年版。 [明]张介宾，『类经』，北京：人民卫生出版社，1964年版。 [宋]朱喜撰，『四书章句集注』，北京：中华书局，1983年版。 [周]左丘明传, [晋]杜预注，[唐]孔颖达正义：『春秋左传正义』, 北京： 北京大学出版社，1999年版。

黄寿祺，张善文撰，『周易译注』，上海：上海古籍出版社，2004年版。 [汉]许慎撰, [清]段玉裁注, 『说文解字注』, 上海: 上海古籍出版社, 1981年版。 
-국문요약-

\section{대순진리회의 수도 요체와 심신 수양}

\section{양옌(楊燕)}

중국사천사범대학

한국의 대순진리회는 증산 성사의 가르침을 숭신하는 종교단체 로서, 한국 사회에 상당한 영향력을 가지고 있다. 1969년 창설된 대순진리회는 포덕 - 교화 - 수도를 삼대 기본사업으로, '음양합덕 · 신인조화·해원상생 - 도통진경'을 종지로, '안심 - 안신 · 경천 · 수 도'를 사강령으로, '성 - 경 - 신'을 수도의 삼요체로 삼고 있다. 또 한 인간개조와 포덕천하- 구제창생 - 보국안민을 통하여 지상천국 을 건설하는 것을 목표로 한다.

대순진리회는 사상적 측면에서 무(巫)와 유(儒) - 불(佛) - 도(道) 를 포용하고 있다. 이러한 대순사상을 바탕으로 대순진리회의 도 인들은 근엄하고 세밀한 실천수도를 수행하는데, 그 내용을 살펴 보면 중국 유-불 - 도의 양생문화와 많은 공통점이 있는 동시에, 또한 뚜렷한 한국 문화의 특색을 띠는 부분도 있다. 이런 면들은 모두 개인적 수도와 사회적 안정을 실현하는 데 큰 도움이 되고 있다.

'안심 · 안신 - 경천 · 수도'의 사강령은 대순진리회의 도인들이 지 켜야 할 가장 기본적인 행위규범이다. '성 - 경 - 신'의 삼요체는 사 강령을 실천하기 위한 내면적 수양으로서 모든 수도활동의 근본이 되는 것이다. 삼요체 중에서 '성'을 가장 근본적인 것으로 생각하 는데, 그 이유는 오직 '성’을 갖춘 사람만이 ‘경'과 '신'을 논할 수 
있기 때문이다. 반대로 마음속에 망념이 있거나 경거망동을 하는 사람들은 상제에 대한 '경'과 '신'을 잃게 된다. '성실함'이라는 내 면적 도덕 품성은 인간으로 하여금 더욱 정직하고 안정되며 오래 지속되게 한다. 뿐만 아니라 '성'은 수도자들로 하여금 더욱 순수 해지고, 어리석음을 버리게 한다. 크나큰 도를 성취하려면 먼저 이 렇게 얼핏 보기에는 어리석지만 끈기 있는 마음이 필요하다. '성' 하면 기운이 솟구쳐 내면이 더욱 안정되고 번뇌는 사라진다. 성심 을 수련하면 마음이 안정되고, 마음이 안정되면 정신이 안정되는 데, 정신이 안정되면 걱정이 사라지기에 몸도 건강해진다. 삼요체 중 '경'과 '신'에 있는 큰 의미 가운데 하나는 상제님에 대한 경배 와 믿음을 끝까지 가지라는 것이다.

'해원상생 - 보은상생'은 대순사상의 가장 중요한 대도(大道) 윤 리로서 도인들의 수도를 인도하는 기본적인 법칙이다. 대순진리회 에서 말하는 해원은 단지 개인 한 사람의 해원이 아니라 우주의 질서를 바로잡는 해원이라는 점에서 중요하다. 그렇기 때문에 대 순진리회 도인들은 개개인으로 시작하여 자신의 원한을 해결할 뿐 만 아니라, 땅의 원한, 천민의 원한, 여인의 원한 등 모든 원을 해 결해 주고자 한다. 즉 삼계의 모든 불평등을 해소하고 불합리한 부분을 바로잡는 것이다. 해원의 다른 측면은 보은이라 할 수 있 다. 해원과 보은은 상보상조의 관계에 있는데, 이는 곧 도인들이 행하는 수도의 양 날개라 생각된다. 해원을 통하여 과거의 장애를 제거하고, 보은을 통하여 현재의 덕을 쌓는 것이다. 보은을 하려면 항상 감사의 마음을 간직해야 한다. 그 의미는 인간관계에 있어서 다른 사람이 베푼 은혜를 항상 고맙게 생각해야 한다는 것이며, 더 나아가 천지가 우리에게 베푼 은혜도 감사하게 생각해야 한다 는 것이다. 모든 원한이 풀어지고, 모든 은혜를 다 갚았을 때 삼계 가 조화롭고 통하게 될 것이다.

대순진리회에서는 도인들의 실천수도 면에서 두 가지 측면을 강 조하는데, 즉 포덕교화와 근언신행이다. 근언신행은 자아발전을 위 
한 도인들의 내적 수련이며, 포덕교화는 도인들이 외부 세상에 대 순사상을 알리고 가르치는 것을 말한다. 양자는 동전의 양면과 같 이 떨어질 수 없는 관계에 있다. 다른 사람을 포덕-교화 하려면 도인들 스스로가 먼저 말과 행동에 조심해야 한다. 왜냐하면 말과 행동을 조심하는 것 자체가 곧 포덕교화에서 다른 사람의 모범이 되기 때문이다.

인생을 살면서 추구해야 할 가장 높은 목표는 덕(德)을 세우는 것이고, 그 다음은 공(功)을 세우는 것이며, 그 다음은 언(言)을 세 우는 것이다. 덕-공 - 언은 세월이 지나도 그 가치가 빛을 바래지 않는다. 이 세 가지 중 한 가지를 이룬 사람이면 불후하다고 할 수 있다. 성인들이 성인으로 칭송 받았던 이유는 모두 육체를 초 월한 덕 - 공 - 언으로 세상을 풍요롭게 했기 때문이다. 그렇기 때 문에 비록 그들이 세상을 떠났다 하더라도 마치 살아있는 것처럼 영원히 추앙되니, 이것을 통하여 영생을 얻는 것이다. '영생(永生)' 만큼 높은 경지에 도달하는 '양생'이 또 어디에 있겠는가? 대순진 리회 실천수도의 최고목표는 바로 인간 내면의 수양을 최고의 경 지로 끌어올리는 것으로서 이는 곧 음양합덕-도통진경이다. 다시 말해서 영원히 불후한 경지에 이르고 만세(萬歲)토록 영생하는 것 이며 신(神) 그리고 성인이 되는 것이다.

주제어 : 대순진리회, 수도, 심신소양

() 투 고 일 : 2013년 8월 31일

() 심 사 기 간 : 2013년 11월 18일 22일

() 게 재 확 정 일 : 2013년 11월 24일 